\title{
Martial arts and combat sports coaching. International framework and sport sciences challenges
}

\author{
Abel FIGUEIREDO* \\ Polytechnic Institute of Viseu (Portugal)
}

5th IMACSSS World Scientific Congress Abstracts, Rio Maior (Portugal), October 6-8

Type: Keynote conference

The practice of human fighting actions, in intentional community environments, created different specificities from institutions such as military, education, artistic and sportive. Usually those practices are labeled in English as Martial Arts and Combat Sports. But sometimes this labels are not sufficient for the complexity understanding (Cynarski, 2012; Nakiri, 2015).

The leadership of this process centered on the practitioner assumed different roles. One of the major roles is the instructor, teacher, director or coach, because they influence practices and performances of practitioners creating practice and performance opportunities that influence the institutional habits permanence and changes, linking practitioners with social realities.

That is why on the International Sport Coaching Framework, coaching is assumed as "a relational, not isolated activity" (ICCE; ASOIF \& LBU, 2013, p.13).

Sport is also social, and the institutionalization of sport is a way to study the permanence and changes on the multiple faces that sport has today from yesterday to tomorrow.

Sport is not only the institutionalization of ancestral pre-sportive activities on one way of "sportivization" with the "character of a civilizing spurt comparable in its overall direction to the 'courtization' of the warriors where the tightening rules of etiquette played a significant part" (Elias \& Dunning, 1986, p.151). Sport, as "the institutionalization of certain practices" in "epistemic relations with other social activities" (Figueiredo, 2009, p.26), should not stay on a static vision based on its foundation but on a basic dynamic idea: Sport continues today its way of development, its way of institutionalization and its way of "sportivization".

The institutionalization of sport forms has been studied by Kent Pearson on the mat of other researchers from the 1970's, as a range of sub-processes, concluding that "Cases can be found [...] in which value patterns emphasizing non-competitiveness and rejecting high degrees of formalization and organization are institutionalized" (Pearson, 1979, p.52). It is interesting to note that today, a "two main coaching categories" are assumed: "participation coaching" and "performance coaching" (ICCE, ASOIF, \& LBU, 2013, p.22).

The study of fight and combat motor actions institutionalization process in different regions and cultures, with different languages and methodologies labeled in English as Martial Arts, Combat Sports, Fighting Activities, etc., make us be confronted with the complexity of martial fight institutionalization, education institutionalization, art institutionalization, sport institutionalization, wellness institutionalization, etc. (Figueiredo, 2009).

This complexity assumes institutional relevance today in terms of major institutions such as SporAccord, regarding rules for members: "Applications from martial arts and combat sports will be considered with the greatest care due to the complex nature and relatively minor differences between their activities" (SPORTACCORD, 2016).

In Martial Arts and Combat Sports, even if we are concerned about concepts and methods, using "pen" and "sword" actions, the development of practices in "'organized combat', 'casual combat' and

*Email: abel.figueiredo@esev.ipv.pt 
'non-combat'” (Figueiredo, 2009, p.28) are a continuous dynamic happening, assuming epistemic and social energy from:

1. Modernity and organized sport, evidencing the rupture with the world of tradition as a modern institutionalization;

2. Postmodernity and casual sport, evidencing low institutionalized context and, many times, against the major institutions;

3. Overmodernity or supermodernity (Augé, 1995) and hypermodernity (Lipovetsky, 2004) as non-sport evidencing the freedom return to the individual in spaces through which they are in transit, experienced in the anonymity of non-place, and in solitude (Augé,1995: 120).

From negatrice of tradition as organized sport represents with modern institutionalization, we understand the integratice modeling linked with multi-vision that surpass the simplicity of a one way of sportivisation. It seems that innovative institutional leaders assumes different and complementary ways as Garry Hamel: rule makers, rule takers and rule breakers. "Rule makers and rule takers are the industry. Rule breakers set out to redefine the industry, to invent the new by challenging the old." (Hamel, 1996: 71).

Analyzing the SporAccord actual development, we can observe an intentional community development creating a "network of institutions" (Fichter, 1971, p.276), on the mat of the "pivotal institution" (ibid, p.278) as International Olympic Committee is, paired by Association of Summer Olympic International Federations (ASOIF), Association of International Olympic Winter Sports Federations (AIOWF), Association of IOC Recognised International Sports Federations (ARISF). And even inside SportAccord new institutional moves such Alliance of Independent Members of SportAccord (AIMS) gained value.

Finally, Martial Arts and Combat Sports coaching is centered on practitioner's performance that is multidimensional (biopsychosocial) stimulating competent coaches and educational programs center on sport sciences networking and responses must model complex problems.

\section{References}

Augé, M. (1992). Non-Lieux - Introduction à une Anthopologie de la Surmodernité, Paris: Seuil / Translation: John Howe (1995). Non-Places - Introduction to an Anthropology of Supermodernity, London: Verso.

Cynarski, W. (2012). Budo, Martial Arts and Combat Sports - Definitions, Ideas, Theories. Research Journal of Budo, 45(3), 233-241.

Elias, N., \& Dunning, E. (1986). Quest for Excitement - Sport and Leisure in the Civilising Process. Oxford UK \& Cambridge USA: Blackwell Publishers.

Fichter, J. (1971). Sociology (2nd ed.). Chicago: University of Chicago Press.

Figueiredo, A. (2009). The Object of Study in Martial Arts and Combat Sports Research Contributions to a Complex Whole. In W. J. Cynarski (Ed.) Martial Arts and Combat Sports Humanistic Outlook (pp. 20-34). Rzeszów: Wydawnictwo Uniwersytetu Rzeszowskiego.

ICCE, ASOIF, \& LBU (2013). International Framework for Coaching - Version 1.2. Champaign, Il.: Human Kinetics.

Lipovetsky, G., \& Charles, S. (2004). Les Temps Hypermodernes, Paris: Graseet \& Fasquelle.

Nakiri, F. (2015). Concept of budo and the history and activities of the Japanese Academy of Budo. Ido Movement For Culture. Journal of Martial Arts Anthropology, 15(1), 11-15.

Pearson, K. (1979). The Institutionalization of Sport Forms. International Review for the Sociology of Sport, 14(1), 51-60.

SPORTACCORD (2016). Definition of Sport. Retrived from http://www.sportaccord.com/about/membership/definition-of-sport.php

Key words: Martial arts; combat sports; coaching; institutionalization. 